\title{
Improved Charcoal Production for Environment and Economics of Blacksmiths: Evidence from Nepal
}

\author{
Rishi Ram Kattel \\ Department of Agricultural Economics and Agribusiness Management, Agriculture and Forestry University, Rampur, Chitwan 0097, \\ Nepal
}

\begin{abstract}
Blacksmiths in Nepal are marginalized and disadvantaged occupational caste, however, very popular for their handicraft works mainly in making iron tools and equipments. With the advancement of technology, there have been many innovative technologies in many other sectors, but blacksmiths in Nepal are still dependent on their indigenous and conventional practices which have direct negative consequences for environment, biodiversity conservation and health. Recently, improved charcoal production technology has been implemented among the 77 blacksmith households in Sindhupalchowk district as a pilot project. However, there is little research about the impact of improved charcoal production on forest resources conservation and people's livelihoods. This study therefore made an effort to explore the impact of improved charcoal production technology and firewood consumption on conserving the environment and promoting sustainable livelihood of marginalized households in rural areas of Nepal. Findings of the study revealed that improved charcoal production technology has positive impacts on forest tree conservation by reducing the fuel wood consumption up to $40 \%$ with $60 \%$ energy efficiency as compared to the traditional system. The improved charcoal production pilot project has reduced annual $\mathrm{CO}_{2}, \mathrm{CH}_{4}$ and $\mathrm{CO}$ emissions in the study area by 2.4-3.1, 3.3-4.3 and 2.6-3.5 tons, respectively. Furthermore, improved charcoal production system increases blacksmiths' welfare through generating social, human and economic capital and quality attributes like environmental sustainability. Introducing improved charcoal production and controlling heavy firewood collection at rural villages of Nepal will help to increase carbon sequestration and reduce the sources of carbon emission in context of global climate change.
\end{abstract}

Key words: Blacksmith, charcoal, climate change, Nepal.

\section{Introduction}

\subsection{Background Information}

Nepal has very unique feature in terms of natural, cultural and ethnic diversity, people have different occupation to sustain their livelihoods, which has direct impact on social and natural environment. Among different ethnic people, blacksmith, locally known as Kami, is one of the communal and disadvantaged ethnic people who are famous for their handicraft works for making iron equipments. Blacksmiths are therefore named after their traditional works and occupation for making iron equipments. In

Corresponding author: Rishi Ram Kattel, assistant professor, research fields: agricultural economics participatory market system development, value chain analysis, water resource management and empirical econometric modeling. E-mail: rrkattel@yahoo.com. the rural areas of Nepal, most of the agricultural equipments, such as "plough”, "small spade”, "sickle” etc., are supplied by these blacksmiths and this is the main source of income for their livelihoods. In advancement of technology, there have been many technology innovations in every sector, but the majority of blacksmiths in Nepal are only dependent on their indigenous and conventional practices, which has direct negative implication in conserving environment and biodiversity. Blacksmiths are practicing same old conventional charcoal making process, which wastes lots of fuel energy. The Kami is traditionally a forest dependent occupation group [1]. Historically, this ethic group has played a key role in social civilization and sustaining small tool based agriculture farming. The Kami belongs to the Hill Dalits' (oppressed) group and most of the households 
have critical poverty. Their representation in political power and the government services are far smaller in comparison to $3.9 \%$ of their total population [2]. In the study conducted by Livelihood Forest Program (LFP) and Nepal Swiss Community Forest Program (NSCFP), about 60\% energy lost during making charcoal through conventional way, which has direct impact on environment degradation due to high amount of carbon emission. During making of charcoal, generally young full grown forest trees are felled down, causing direct negative consequences in biodiversity conservation.

In the context of Sindhupalchowk district, there are around 4,080 population of blacksmiths, who are basically dependent on their conventional profession of making agricultural iron equipments and agriculture farming [3]. In Sindhupalchowk, most of blacksmiths are under poverty; their socio-economic conditions are very poor. Most of them are also dependent on agriculture farming besides their indigenous profession. They have very hard time to run their profession due to lack of charcoal. Almost all community forests user groups (CFUGs) have been prohibited to make charcoal within their community forest areas in open pit system. Further, the negative relation with household size and positive relationship with forest size for the probability of charcoal demand indicate a pessimistic future prospect for Kami [4]. In this connection, an integrated energy and environmentally friendly technologies along with income generating opportunities through non timber forest products (NTFP) management could help to solve existing problem and preserve traditional handicrafts works of blacksmiths. So the implementation of improved charcoal production project has been focusing on devolving some groups of blacksmiths' population to initiate integrated environmental activities, which could ensure conservation of environment as well as provide opportunity for income generation to sustain their livelihoods. The existing CFUGs have been mobilizing to introduce energy efficiency technology, like bio-briquette, improved cooking stove, biogas, etc., and promote NTFP management within and outside community forest areas.

\subsection{Charcoal Production Technology and Environmental Impacts}

Charcoal is generally related to energy; it is no doubt that energy manifests the whole cosmos. Much has been described about the energy as its manifestation and conversion into various forms in pre-Vedic literature. Charcoal is the wood charred in the absence of air. In slightly more technical terms, the actual process is destructive distillation of organic matter in a near oxygen free environment. Any kind of wood and biomass can be used to make charcoal. However, if softwood is used, it will make soft charcoal and therefore burn quicker. Most charcoal is made from the hardwoods, which are common in most areas: ash, hickory, oak and hard maple. The main thing to watch is to not mix a load with soft and hard woods. If you stop your burn when the soft woods are charcoal, the hardwoods will not be ready, and if you continue the burn for the hardwoods, the soft wood will burn clear to ashes. Charcoal is produced through the pyrolysis (carbonization or destruction distillation) of carbonaceous materials, which is dominantly medium to dense solid wood, such as oak, hickory, beech, birch and hard maple, etc.. Nevertheless, other types of wood, such as softwood, nutshells, fruit pits and vegetable wastes, can be used too, especially for charcoal briquettes. There are different methods and techniques used for production. In many developing countries, traditional method of production in earth pits and earth kilns are still in use, as well as advanced types of small scale production in earth kilns with chimneys and steel or brick kilns [5]. Whereas, in large scale industrial production, batch-wise operation in multiple brick or metal kilns and continually operation in multiple health retorts are used [6]. The named technologies differ in the efficiency of 
production, resulting in different energy efficiency, product quality, product yields and emissions into the environment. For example, for production of $1 \mathrm{~kg}$ of charcoal in earth pits and traditional kilns, 8-12 kg of wood is needed; while in improved traditional kilns and for the industrial production, 4-8 kg and 3-4 kg of wood is needed, respectively [7].

The by-products of charcoal production are pyroaxids, primary acetic acid and methanol, tars, heavy oil (wood vinegar) and water, the majority of which is emitted into the environment with the kiln exhaust. The emissions into the air include gaseous emission of carbon monoxide (CO), carbon dioxide $\left(\mathrm{CO}_{2}\right)$, methane $\left(\mathrm{CH}_{4}\right)$, ethane and volatile organic compounds (VOC); emissions of the particular matter (PM) come from the uncombusted tars and charcoal dust, and pyroacids that may form aerosol emission [7]. The level of emissions depends highly on the technology used for the production, the temperature developed during the pyrolysis as well as the moisture content of the wood. The level of $\mathrm{CO}_{2}$ emissions from traditional charcoal production in several Africa countries has been reported to range from $450 \mathrm{~g} / \mathrm{kg}$ of charcoal production to $550 \mathrm{~g} / \mathrm{kg}$ of charcoal production, while the emission of $\mathrm{CH}_{4}$ is about 700 $\mathrm{g} / \mathrm{kg}$ of charcoal production, $\mathrm{CO}$ is $450-650 \mathrm{~g} / \mathrm{kg}$ of charcoal production and non-methane hydrocarbons (NMHC) is $10-700 \mathrm{~g} / \mathrm{kg}$ of charcoal production, all in $\mathrm{C}$ equivalent units weighted by 20 years GWP [8]. Such levels of emissions, especially concerning methane, which has the highest warming potential, can be perceived as significantly environmental impact on both regional and global level [7]. Furthermore, tests conducted on charcoal production management showed that the incineration of flue gases at about $1,000{ }^{\circ} \mathrm{C}$ allow destruction of $99 \%$ of the mass of pollutants apart from $\mathrm{CO}_{2}$ [9]. Charcoal contains approximately $80 \%$ fixed carbon, $24 \%$ of volatile compounds, $4 \%$ of ash, $0.53 \%$ of nitrogen and $0.03 \%$ of sulfur. Long term inhalation of particular matter, carbon monoxide, nitrogen and sulphate oxides as well as other volatile compounds that are emitted during the charcoal burning, may lead to respiratory problems and ultimately diseases, such as acute respiratory infection (ARI), otitis media (middle ear infection), chronic obstructive pulmonary disease (COPD), asthma, lung cancer, low weight and others [10].

\subsection{Objectives}

The aim of this study was to examine the impact of improved charcoal production on conserving environment and sustainable livelihoods of blacksmiths in Nepal—a case study from project implemented in Sindhupalchowk district. The central question of this study was to assess the improved kiln method of charcoal production technique as opposed to tradition system to provide better livelihood opportunities to the blacksmiths and environmental sustainability in local and national scenarios.

\subsection{Limitations}

Due to the low literacy rate among the respondent of blacksmiths, quantification of environment and health benefits might not be acquired in full account. Furthermore, actually an emission of greenhouse gases (GHG) was not recorded scientifically before and after improved charcoal production project.

\section{Methodology}

For the purpose of the research, a total 77 households were interviewed in the improved charcoal production pilot project implemented at three village development committees (VDCs), namely, Sipapokhare-8, Kunchock-6 and Bhotasipa-5 of the Sindhupalchowk district in 2010. To complement the household survey, a series of formal and informal case studies and focus group discussions (FGD) with Anvil Smithy Groups (ASG) have also conducted along with the interview of expert from improved charcoal production implementing partner (ICPIP), executive committee 
and rural energy sector specialists. The FGD and expert interviews provided qualitative information for conducting a strength, weakness, opportunity and threats (SWOT) analysis to highlight SWOT of improved charcoal production and handle as well as contractual relationships among ASG, ICPIP and CFUG.

Through the interviews, FGD and site visit information on the specifics of the charcoal production process and its profitability in environmental, health and safety aspects were collected and analyzed. In both FGD and case studies, special regard is given to the environmental and socio-economic aspects of improved charcoal production system in community. Furthermore, secondary data from second progress report of the project and related literatures on charcoal production and emissions have been concerned.

The methodologies followed a two-step approach. First, environmental aspect of the charcoal production before-after project on fuel wood consumption, energy efficiency and carbon emission as well as health aspects was undertaken to ascertain the relative environmental profitability of different modes of charcoal production in blacksmiths community of the rural areas. Second, sustainable livelihood of blacksmiths was estimated through the analysis of different socio-economic capitals generation after implementing improved charcoal production technique in blacksmithing community. The methodology of research framework is illustrated in Fig. 1.

\section{Results and Discussion}

In the following, first the environmental impacts assessment and then socio-economic aspects of sustainable livelihood of blacksmiths in project area are presented.

3.1 Environmental Aspect of Improved Charcoal Production

There are various environmental and socio-economic benefits associated with the improved charcoal production technique through pits kiln method in the study area. However, biomass resources themselves are under threat from overuse, creating additional environmental challenges. In the study area,
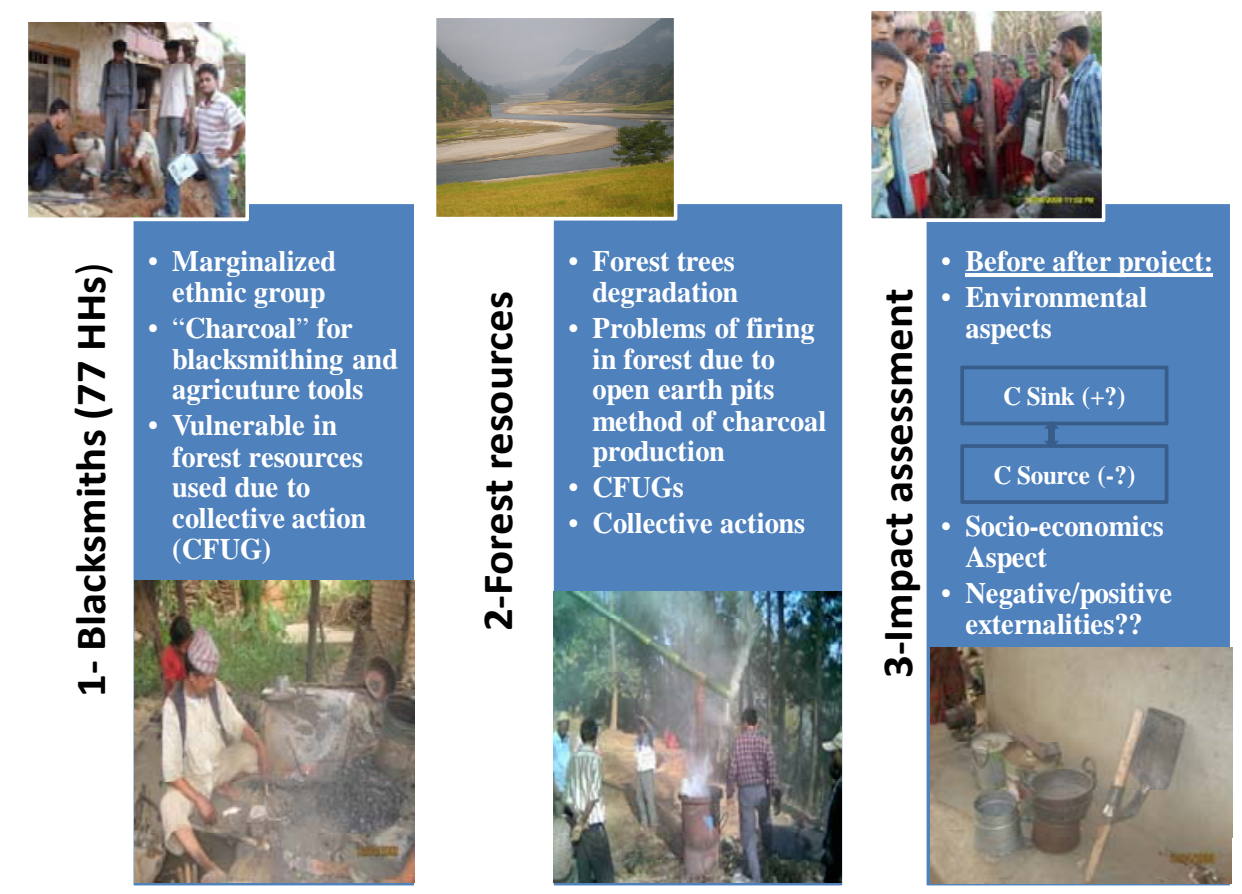

Fig. 1 Conceptual research framework for project impact assessment. 
three different improved pits kiln have been prepared for ASG participatory experiment to compare with a traditional method. The results showed that 2.81, 3.76 and $3.57 \mathrm{~kg}$ fire wood of chestnut (Castanea dentate) in charring drum kiln, improved pit kiln and mud-bricks kiln, respectively, were required for making $1 \mathrm{~kg}$ good charcoal, while $7.14 \mathrm{~kg}$ fire wood of chestnut were required for making $1 \mathrm{~kg}$ good charcoal in the traditional and conventional method. In average, $7.14 \mathrm{~kg}$ fuel woods was consumed to make 1 $\mathrm{kg}$ charcoal in the traditional way in earth pits, while with small technology modifications in old practices, i.e., improved kilns, $3.38 \mathrm{~kg}$ fire wood was required for making $1 \mathrm{~kg}$ charcoal (Table 1). Data from blacksmiths participatory experience for charcoal production showed that $40 \%$ wood consumption is reduced in improved pits kiln method as compared to traditional earth pits.

In community level practices after project implementation, $1 \mathrm{~kg}$ charcoal has been produced from $5 \mathrm{~kg}$ fire wood (from different species) in traditional method of earth pit, while same amount of charcoal has been produced from $3 \mathrm{~kg}$ fire wood by improved pits kiln method. If all 77 households have been implementing improved pit kiln method of charcoal production, they are able to save around $38,500-50,050 \mathrm{~kg}$ of fire wood (i.e., equivalent to 171-223 forest trees) annually. The summary of environmental benefits from improved charcoal production project is presented in Table 2.

Table 1 Comparative analysis of making charcoal (from $100 \mathrm{~kg}$ fire wood of chestnut).

\begin{tabular}{lllll}
\hline \multirow{2}{*}{ Items produced } & \multirow{2}{*}{$\begin{array}{l}\text { Traditional } \\
\text { method (in kg) }\end{array}$} & \multicolumn{3}{c}{ Improved kiln method (in kg) } \\
\cline { 3 - 5 } & Charring drum & Improved pit & Mud and brick pit \\
\hline Good charcoal & 14.00 & 35.60 & 26.60 & 28.00 \\
Unburnt & 5.00 & 8.30 & 8.30 & 10.00 \\
Ash, dust and other & 3.50 & 1.60 & 1.60 & 4.16 \\
Fire wood required for 1 kg charcoal production & 7.14 & 2.83 & 3.74 & 3.57 \\
\hline
\end{tabular}

Table 2 Environmental benefits from improved charcoal production.

\begin{tabular}{|c|c|c|c|}
\hline Difference scenario & $\begin{array}{l}\text { Before project } \\
\text { (traditional charcoal) }\end{array}$ & $\begin{array}{l}\text { After project } \\
\text { (improved charcoal) }\end{array}$ & Impacts \\
\hline \multirow{3}{*}{$\begin{array}{l}\text { Annual fire wood } \\
\text { required for } 77 \\
\text { blacksmith HHs }\end{array}$} & $\begin{array}{l}1 \mathrm{HH} \text { requires } 250 \mathrm{~kg} \text { charcoal } \\
\text { annually; }\end{array}$ & $\begin{array}{l}1 \mathrm{HH} \text { require } 200-250 \mathrm{~kg} \text { charcoal } \\
\text { annually; }\end{array}$ & \multirow{3}{*}{$\begin{array}{l}\text { 50,050- 38,500 kg firewood } \\
\text { consumption reduced annually } \\
\text { in project area (40\%-51\% fire } \\
\text { wood consumption reduced). }\end{array}$} \\
\hline & $\begin{array}{l}77 \text { HHs require } 250 \times 77=19,250 \mathrm{~kg} \\
\text { charcoal; } \\
1 \mathrm{~kg} \text { charcoal making required } 5 \mathrm{~kg} \\
\text { fuel wood; }\end{array}$ & $\begin{array}{l}77 \text { HHs require } 200-250 \times 77= \\
15,400-19,250 \text { kg charcoal; } \\
1 \text { kg charcoal making required } 3 \\
\text { kg charcoal; }\end{array}$ & \\
\hline & $\begin{array}{l}77 \text { HHs required } 19,250 \times 5=96,250 \\
\text { kg fire woods. }\end{array}$ & $\begin{array}{l}77 \text { HHs require } 15,400-19,250 \times \\
3=46,200-57,750 \mathrm{~kg} \text { fire wood. }\end{array}$ & \\
\hline $\begin{array}{l}\text { Fire wood saved (sink } \\
\text { source increased) }\end{array}$ & $\begin{array}{l}\text { Required wood for charcoal to the } 77 \\
\text { HHs = 96,250 kg; } \\
\text { Annual forest trees required = } \\
\text { 96,250/225 = } 428 \text { trees (average } 225 \\
\text { kg fire wood from one forest tree). }\end{array}$ & $\begin{array}{l}\text { Required wood for charcoal to the } \\
77 \text { HHs = 46,200-57,750; } \\
\text { Annual forest trees required = } \\
46,200-57,750 / 225=205-257 \\
\text { trees. }\end{array}$ & $\begin{array}{l}\text { 171-223 forest trees } \\
\text { conservation by improved } \\
\text { charcoal production. }\end{array}$ \\
\hline $\begin{array}{l}\mathrm{CO}_{2} \text { emission reduction } \\
\text { (carbon source reduced) } \\
\text { (estimated in project } \\
\text { implementing area) }\end{array}$ & $\begin{array}{l}\mathrm{CO}_{2} \text { emission from } 8 \mathrm{~kg} \text { fire wood } \\
\text { around } 450-550 \mathrm{~g} \mathrm{CO}_{2}(*) ; \\
96,250 \mathrm{~kg} \text { fire wood produced } 6.02 \\
\text { tons } \mathrm{CO}_{2} \text {. }\end{array}$ & $\begin{array}{l}46,200-57,750 \mathrm{~kg} \text { fire wood } \\
\text { produced 2.89-3.61 tons } \mathrm{CO}_{2} \text {. }\end{array}$ & $\begin{array}{l}2.41-3.13 \text { tons } \mathrm{CO}_{2} \text { emission } \\
\text { annually reduced from the } \\
\text { improved charcoal production. }\end{array}$ \\
\hline $\begin{array}{l}\text { Emissions of other gases } \\
\text { (estimated in project } \\
\text { implementing area) }\end{array}$ & $\begin{array}{l}\text { From } 8 \mathrm{~kg} \text { fire wood, } 700 \mathrm{~g} \mathrm{CH}_{4} \text { and } \\
450-650 \mathrm{~g} \text { CO produced }(*) ; \\
\text { From } 96,250 \mathrm{~kg} \text { fire wood, } 8.42 \text { tons } \\
\mathrm{CH}_{4} \text { and } 6.62 \text { tons CO produced. }\end{array}$ & $\begin{array}{l}\text { From } 46,200-57,750 \text { kg fire wood, } \\
4.04-5.05 \text { tons } \mathrm{CH}_{4} \text { and 3.12-3.97 } \\
\text { tons } \mathrm{CO} \text { produced. }\end{array}$ & $\begin{array}{l}\text { 3.37-4.38 tons } \mathrm{CH}_{4} \text { and } 2.65-3.5 \\
\text { tons } \mathrm{CO} \text { emissions annually } \\
\text { reduced from improved } \\
\text { charcoal. }\end{array}$ \\
\hline
\end{tabular}

Source: project progress report, HH survey and participatory experiment, 2008-2010. *From African countries scenario reports [8]. HH: Household. 
Due to decrease of $40 \%$ to $51 \%$ fire wood consumption from improved charcoal production with $60 \%$ energy efficiency, the time spent for making charcoal is saved among the blacksmith for use in more productive activities. In addition, the improved charcoal production project seems to be viable option for increasing carbon sink source by reducing fire wood consumption and deforestation as well as reducing carbon and other GHG emissions in the surrounding environment. It is estimated that around 2.41-3.31 tons of $\mathrm{CO}_{2}, 3.37-4.38$ tons of $\mathrm{CH}_{4}$ and 2.65-3.5 tons of CO emissions have been reduced annually after project implementation with $77 \mathrm{HHs}$ of blacksmiths. Apart from the impacts on the environment, improved charcoal production in pits kiln has positive impact on human health. During focus group discussion with ASG member Mr. Tej Bdr. BK (35 years age), the author asked, "Why do you involve in improved pit kiln method of charcoal production?” and “what are the benefits for you?” He said, “Basically, what I am looking to do is: live sustainability $\{\ldots .$. because it is the way that I always want to go". Another blacksmith added, "Improved charcoal production in pits kiln has seen a positive impact on their health especially less respiratory problem and ultimately diseases, such as acute respiratory infection (ARI), eye stress and otitis media (middle air infection)”.

\subsection{Livelihood Sustainability Aspects}

Improved livelihood of the blacksmith has also been envisaged from the improved household income resulting from increased income generating and employment opportunities in the sustainable improved charcoal production system and consumption framework. Furthermore, in order to analyze the factor which determines welfare effect of improved charcoal production project on blacksmiths, the author has developed analytical framework based on economic, social and human capitals generating on livelihood with environmental sustainability model. There are various socio-economic benefits addressing economic, social and human capital associated in improved charcoal production system through pits kiln method. Furthermore, the capacities of the local blacksmiths to initiate and sustain improved charcoal production project, the quality and quantity of charcoal production would be strengthened. Other skills gained among the project beneficiaries would include small-enterprise management, market orientation and supply chain development of iron equipments. That is presented in Table 3.

\section{Conclusions and Policy Recommendations}

A number of advantages have been associated with the improved charcoal production technology system.

Table 3 Welfare effect of improved charcoal production project on blacksmithing community.

\begin{tabular}{|c|c|}
\hline Livelihood assets & Impacts on sustainable livelihood \\
\hline Economics capital & $\begin{array}{l}\text { Revolving fund for mobilizing in group for skill based equipment production, time save for making charcoal, } \\
\text { wood vinegar production (quality in testing phase), reduced Balipartha", saving and credit program (NRs 1,500 } \\
\text { to 2,000 more income/month/HH after project): significant impact. }\end{array}$ \\
\hline Social capital & $\begin{array}{l}\text { Networks, ASG formation and mobilization, social empowerment, group membership, meeting in each month, } \\
\text { PIA and action plan: significant impact. }\end{array}$ \\
\hline Human capital & $\begin{array}{l}\text { Training received on improved charcoal production, briquette, entrepreneurship development for blacksmiths } \\
\text { and other income generation: gradual impact. }\end{array}$ \\
\hline $\begin{array}{l}\text { Institution (process } \\
\text { and structure) }\end{array}$ & $\begin{array}{l}\text { Organization structure with specific implications for improved charcoal production among blacksmith } \\
\text { community, interaction with ASG, adoption of improved charcoal making in community: some gradual impact } \\
\text { on blacksmith HHs. }\end{array}$ \\
\hline Vulnerability & Due to CFUG regulation and restriction of collective action on forest resources used. \\
\hline
\end{tabular}


It is designed to minimize material and energy losses during charcoal making process and could protect extra forest trees for conserving environment. The smoke emission from the improved kiln method of charcoal production is far less as compared to an open fire traditional method of charcoal production. Not only improved kiln method of charcoal production reduces the deforestation epidemic in Nepal, but also reduces the prevalence of respiratory illness among blacksmiths' community; it provides high yield and better quality of charcoal with other socio-economic benefits. Improved charcoal production project in Sindhupalchowk has created an income sources for the rural poor blacksmiths, replaced traditional charcoal production with improved kiln method and educated about environmental and health benefits in society. It has also been observed that the indoor and outdoor air pollution and energy consumption situation have been improved by using improved charcoal production technique.

Improved charcoal production project has been estimated that around $40 \%-51 \%$ of fire wood consumption reduced annually. Furthermore, around 2.41-3.13 tons of $\mathrm{CO}_{2}, 3.37-4.38$ tons of $\mathrm{CH}_{4}$ and 2.65-3.5 tons of $\mathrm{CO}$ emissions have been annually reduced after implementing improved charcoal production project in 77 households of blacksmiths in Sindhupalchowk district. Thus, project has significantly increase carbon sink source and reduce GHG in environment. So, significant impact on conserving environment has been seen in improved charcoal production project. Nevertheless, there are various socio-economic benefits addressing economic, social and human capital associated in improved charcoal production project framework have been seen in both structure and process. Nevertheless, it has been observed that blacksmiths consume $5-7.14 \mathrm{~kg}$ fuel woods to make $1 \mathrm{~kg}$ of charcoal in their conventional and traditional way, while with small technology modifications in their practices in the improved pit kiln method, $1 \mathrm{~kg}$ quality charcoal can be made from $3-3.38 \mathrm{~kg}$ of fuel woods, which indicates urgent need of interventions to improve blacksmiths traditional practices and to reduce and mitigate environmental degradation in the context of global climate change.

The improved charcoal production project has the potential for application in the entire hilly regions of Nepal with wide array of social, economic and environmental gains. If well designed and implemented, this technology is potentially cost-effective with high chances of success for increasing carbon sink by conserving forest trees and reducing carbon source due to community participating approach. However, the issue of affordability also needs to be examined from the perspective of both costs and reduction in deforestation.

\section{Acknowledgments}

The author is thankful to United Nations Development Program/Small Grant Project (UNDP/GEF/SGP) and Community Development for Environmental Conservation Forum (CDECF) Sindhupalchowk District for technical and financial supports. This research has been done from impact assessment of the project "Improved Economics of Blacksmiths for Conserving Environment and Promoting Sustainable Livelihoods” in Sindhupalchowk District funding by UNDP/GEF/SGP and implementing by CDECF. The author duly acknowledges the invaluable support in project impact assessment especially Mr. Iswor Barshila, Mr. Govinda Sapkota, Mr. Saradha Sapkota and Mr. Chintamani Sharma. Last but not least thanks go to all blacksmiths and ASG for their valuable experiences and time during project impact assessment.

\section{References}

[1] Hobley, M. 1996. Participatory Forestry: The Process of Change in India and Nepal. London: Rural Development Forestry Oversees Development Institute.

[2] National Planning Commission (NPC). 2003. The Tenth 
Plan 2002-2007 (Poverty Reduction Strategy Paper: Summary). National Planning Commission, Kathmandu, Nepal.

[3] District Development Committee (DDC). 2000. Sindhupalchowk District Annual Report, Nepal.

[4] Dhakal, B. 2006. "The Issue of Oppresses Groups' Access to Collectively Managed Resources: An Empirical Analysis.” Banko Janakari 16 (1): 25-31.

[5] Stassen, H. E. 2002. "Department in Charcoal Production Technology.” An International Journal of Forest and Forest Industry 53 (4): 34-5.

[6] United States Environmental Protection Agency (EPA). 1995. "Emission Factor Documentation for AP-42: Section 10.7 Charcoal.” EPA, USA. Accessed August 15, 2013. http://www.epa.gov/ttn/chief/ap42/ch10.

[7] FAO. 2008. "Environmental Aspects of Charcoal Production in Croatia.” A Part of Deliverables of FAO Project: TCP/CRO/3101 (A), Development of a
Sustainable Charcoal Industry, North-West Croatia Regional Energy Agency, Zagreb, Croatia. Accessed March 10, 2013. http://www.drveniugljen.hr.

[8] Bailis, R., Pennise, D., Ezzati, M., Kammen, D. M., and Kitayi, E. 2004. "Impact of Greenhouse Gas and Particular Matter Emissions from Woodfuel Production and End-Use in Sub-Saharan Africa.” Renewable and Appropriate Energy Laboratory (REAL), University of California. Accessed January 1, 2014. http:/www.rael.berkeley.edu/old-site/OA5.1.pdf.

[9] Halouani, K., and Farhat, H. 2003. "Depollution of Atmospheric Emissions of Wood Pyrolysis Furnaces.” Renewable Energy 28 (1): 129-38.

[10] Ezzati, M., and Kammen, D. M. 2002. “The Health Impacts of Exposure to Indoor Air Pollution from Solid Fuels in Developing Countries: Knowledge, Gaps and Data Needs.” Environmental Health Perspectives 110 (11): 1057-68. 